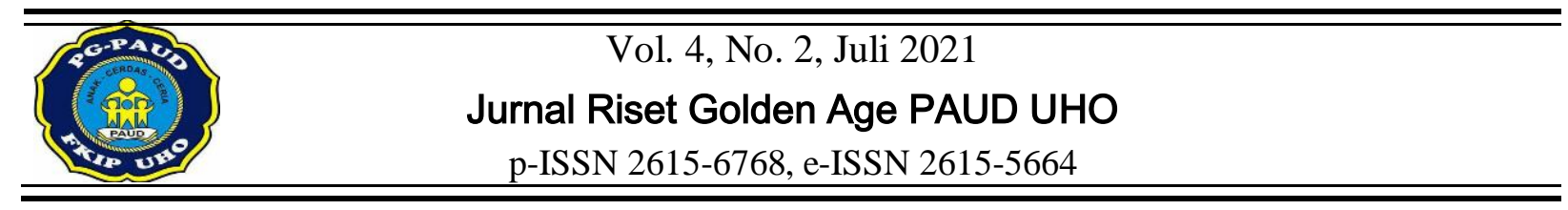

\title{
IMPLEMENTASI KEGIATAN KELAS MEMASAK UNTUK MENINGKATKAN KEMAMPUAN MOTORIK HALUS ANAK
}

\author{
Nur Rezkyani ${ }^{1{ }^{*}}$, Muamal Gadafi ${ }^{1)}$, Dorce Banne Pabunga ${ }^{1)}$ \\ ${ }^{1}$ Jurusan PG-PAUD, Universitas Halu Oleo. Jln. H.E.A Mokodompit, Kendari 93232, Indonesia. \\ *Email: nur.rexky126@gmail.com
}

\begin{abstract}
Abstrak
Penelitian ini bertujuan untuk meningkatkan kemampuan motorik halus anak melalui kegiatan kelas memasak di kelompok B1 RA Wildaanun Rabbaniyyun Kendari. Subjek dalam penelitian ini adalah guru dan anak yang berjumlah 15 orang dengan rentang usia 5-6 tahun. Hasil analisis data observasi aktivitas mengajar guru dan aktivitas belajar anak pada siklus I diperoleh persentase ketercapaian sebesar 78\%. Hasil belajar anak pada Siklus I dalam meningkatkan kemampuan motorik halus melalui kegiatan kelas memasak diperoleh persentase ketercapaian pada siklus I sebesar $74 \%$. Hasil analisis data observasi aktivitas mengajar guru dan aktivitas belajar anak pada siklus II mengalami peningkatan yang signifikan dengan memperoleh ketercapaian sebesar 93\%. Hasil belajar anak pada Siklus II dalam meningkatkan kemampuan motorik halus melalui kegiatan kelas memasak diperoleh persentase ketercapaian pada siklus II sebesar 87\%. Dengan demikian, dapat disimpulkan bahwa kemampuan motorik halus anak dapat ditingkatkan melalui kegiatan kelas memasak di kelompok B1 RA Wildaanun Rabbaniyyun Kendari.
\end{abstract}

Kata kunci: anak usia dini, kelas memasak, motorik halus.

\section{IMPLEMENTATION OF COOKING CLASS ACTIVITIES TO IMPROVE CHILDREN'S FINE MOTOR ABILITY}

\begin{abstract}
This study aims to improve children's fine motor skills through cooking class activities in group B1 RA Wildaanun Rabbaniyyun Kendari. The subjects in this study were teachers and children, totaling 15 people with an age range of 5-6 years. The results of the data analysis of observations of teacher teaching activities and children's learning activities in the first cycle obtained the percentage of achievement of $78 \%$. Children's learning outcomes in Cycle I in improving fine motor skills through cooking class activities obtained the percentage of achievement in Cycle I of 74\%. The results of the analysis of observational data on teacher teaching activities and children's learning activities in cycle II experienced a significant increase by obtaining an achievement of 93\%. The learning outcomes of children in Cycle II in improving fine motor skills through cooking class activities obtained the percentage of achievement in Cycle II of $87 \%$. Thus, it can be concluded that children's fine motor skills can be improved through cooking class activities in group BI RA Wildaanun Rabbaniyyun Kendari.
\end{abstract}

Keywords: early childhood, cooking classes, fine motor skills.

\section{PENDAHULUAN}

Pendidikan anak usia dini merupakan pondasi utama untuk mengoptimalkan kemampuan dasar anak untuk menerima proses pendidikan ditahap selanjutnya. Menurut Rindaningsih (Nur, Hafina, \& Rusmana, 2020) pendidikan anak usia dini adalah sebuah program pembinaan yang dilakukan pada anak usia 0 sampai 6 tahun agar anak memiliki kesiapan pada pendidikan selanjutnya. Kemudian menurut (Fardiah, Murwani, \& Dhieni, 2020) pada usia dini merupakan masa emas dalam pertumbuhan dan perkembangan baik secara fisik, emosional, sosial dan intelektual. Pada masa ini dibutuhkan stimulasi 
secara optimal sehingga potensi yang dimiliki oleh anak dapat berkembang dan bertumbuh secara optimal.

Proses pertumbuhan dan perkembangan anak usia dini perlu diperhatikan lebih khusus, karena akan menentukan pada jenjang usia selanjutnya. Salah satu yang perlu diperhatikan dalam proses pertumbuhan dan perkembangan anak usai dini adalah perkembangan kemampuan motorik. Menurut (Pitaloka, Ineu, \& Umar, 2015) perkembangan motorik merupakan suatu proses yang terjadi sejalan dengan bertambahnya usia secara bertahap dan berkesinambungan gerakan pada individu yang meningkat dari keadaan sederhana, tidak terorganisasi, dan tidak terampil kearah performa gerak yang lebih kompleks dan terorganisasi dengan baik. Kemudian menurut Sumartini (Pura \& Asnawati, 2019) perkembangan motorik meliputi pengembangan motorik halus (fine motor) dan motorik kasar (gross motor) yang berguna untuk pertumbuhan dan kesehatan anak. Perkembangan motorik halus merupakan perkembangan gerakan anak yang menggunakan otot kecil atau sebagian anggota tubuh tertentu yang dipengaruhi oleh kesempatan anak untuk belajar dan berlatih. Hal ini juga didukung pendapat Susanto (Indraswari, 2012) bahwa motorik halus adalah gerakan halus yang melibatkan bagian-bagian tertentu saja yang dilakukan oleh otot-otot kecil saja, karena gerakan halus ini memerlukan koodinasi yang cermat dan tidak memerlukan tenaga yang besar.

Berdasarkan observasi awal yang dilaksanakan oleh peneliti di kelompok B1 RA Wildaanun Rabbaniyyun Kendari, tentang kemampuan motorik halus anak menunjukkan bahwa perkembangan motorik halus anak sudah mulai berkembang namun masih membutuhkan kegiatan baru atau media yang baru untuk merangsang jari-jari anak sehingga dapat berkembang dengan maksimal. Selain itu, untuk menghindari kebosanan anak terhadap media yang digunakan secara berulang. Oleh karena itu, untuk mengatasi permasalahan tersebut dalam pengembangan kemampuan motorik halus anak saat proses pembelajaran, penulis menghadirkan sebuah kegiatan yang dapat merangsang pengembangan kemampuan motorik halus anak melalui kegiatan memasak di kelas. Data hasil observasi awal dan wawancara dengan guru kelompok B RA Wildaanun Rabbaniyyun Kendari yang dilakukan penulis mengenai kemampuan motorik halus anak menunjukkan bahwa terdapat 4 orang anak yang memperoleh bintang (***) atau Berkembang Sesuai Harapan (BSH) dengan presentase $26,67 \%, 2$ anak yang memperoleh bintang $(* * * *)$ atau Berkembang Sangat Baik (BSB) dengan presentase 13,33\%, terdapat 7 anak didik yang memperoleh nilai bintang $(* *)$ atau mulai berkembang (MB) dengan presentase $46,67 \%$ dan terdapat 2 anak didik yang memperoleh nilai $\left(^{*}\right)$ atau belum berkembang (BB) dengan persentase 13,33\%. Tingkat keberhasilan anak pada observasi awal adalah $40 \%$, namun belum mencapai standar keberhasilan yang ditentukan yaitu $85 \%$. Oleh karena itu, perlu adanya tindakan perbaikan yang harus dilakukan agar dapat meningkatkan keberhasilan belajar anak yang rendah tersebut agar anak mendaptkan hasil yang maksimal sesuai dengan indikator keberhasilan.

Berdasarkan pada permasalah di atas, maka perlu dilakukan inovasi dalam kegiatan pembelajaran agar kegiatan pembelajaran dapat menarik perhatian anak-anak untuk fokus pada proses pembelajaran itu sendiri. Peneliti dalam penelitian ini telah merancang suatu kegiatan pembelajaran yang menarik dan seru untuk dilakukan anak didik, sehingga dapat memberikan stimulus pada peningkatan kemampuan motorik halus anak. Kegiatan kelas memasak adalah kegiatan yang akan diterapkan dalam penelitian ini dengan tujuan dapat meningkatkan kemampuan motorik halus anak. Menurut (Rasid, Wondal, \& Samad, 2020) kegiatan kelas memasak adalah salah satu kegiatan menyenangkan yang secara langsung melibatkan anak untuk bergerak dan berkreasi dengan menggunakan jari-jari tangan mereka. Kemudian hasil penelitian yang dilakukan oleh (Nurhapita, Enoh, \& Inten, 2019) mengatakan bawah jika di tinjau dari segi perencanaan, pelaksanaan dan evaluasi, maka program kegiatan kelas memasak bagi anak usia dini dapat meningkatkan aspek perkembangan anak usia dini terutama perkembangan motorik halus anak. Untuk itu, berdasarkan pada pendapat diatas peneliti akan menggunakan kegiatan memasak dalam pembelajaran di kelompok B1 RA Wildaanun Rabbaniyyun Kendari dengan tujuan dapat meningkatkan mempuan motorik halus anak.

Penelitian ini bertujuan untuk meningkatkan kemampuan motorik halus anak melalui kegiatan kelas memasak di kelompok B1 RA Wildaanun Rabbaniyyun Kendari. 


\section{METODE}

Jenis penelitian yang digunakan adalah Penelitian Tindakan Kelas. Penelitian ini bertempat di kelompok B RA Wildaanun Rabbaniyyun Kendari pada semester ganjil tahun ajaran 2019/2020. Subjek penelitian ini adalah guru dan anak didik yang berjumlah 15 orang dengan rentan usia 5-6 tahun.

Adapun faktor-faktor yang diteliti dan diamati dalam penelitian ini adalah; a) faktor guru, aktivitas mengajar guru, b) faktor anak, aktivitas belajar dan hasil belajar anak dalam mengikuti kegiatan pembelajaran, c) hasil belajar anak.

Pengumpulan data dalam penelitian ini dilakukan dengan observasi, dokumentasi, dan wawancara. Observasi dilakukan untuk mengamati subjek penelitian dari sebelum hinggal sesudah pelaksanaan tindakan penelitian guna memperoleh informasi berupa data hasil pengamatan. Dokumentasi dilakukan untuk memperoleh data mengenai variabel penelitian berupa catatan, transkrip, buku, dan lain sebagainya. Dokumentasi juga berupa foto guru dan peneliti pada saat proses penelitian dilakukan sebagai bukti pelaksanaan kegiatan lapangan. Wawancara dilakukan untuk memperkuat data yang telah diperoleh dari observasi dan dokumntasi. Wawancara dilakukan dengan percakan langsung baik dengan anak maupun orang tua.

Tehnik analisis data yang digunakan adalah dengan menggunakan analisis deskriptif. Metode analisis deskriptif adalah metode yang menjelaskan atau menggambarkan fenomena penelitian secara objektif. Analisis data merupakan cara yang dilakukan untuk mengetahui keefektifan suatu metode dalam kegiatan pembelajaran. Pengelolaan data dalam penelitian ini disesuaikan dengan teknik penilaian di TK yaitu dengan menggunakan tanda sebagai berikut: $*=$ belum berkembang $(\mathrm{BB}),{ }^{* *}=$ mulai berkembang $(\mathrm{MB}), * * *=$ berkembang sesuai harapan (BSH), dan $* * * *=$ berkembang sangat baik (BSB), (Angraeni, Arvyaty, \& Salim, 2018).

Tabel 1. Kategori Keberhasilan Klasikal

\begin{tabular}{ccc}
\hline Persentase & Kategori & Simbol \\
\hline $95 \%-100 \%$ & BSB & $* * * *$ \\
\hline $85 \%-94 \%$ & BSH & $* * *$ \\
\hline $75 \%-84 \%$ & MB & $* *$ \\
\hline$<75 \%$ & BB & $*$ \\
\hline
\end{tabular}

Indikator keberhasilan dalam penelitian ini adalah indikator proses dan indikator hasil (nilai). Dari segi proses, tindakan dikatakan berhasil apabila hasil observasi terhadap guru dan anak telah mencapai presentase minimal $85 \%$ sesuai dengan skenario kegiatan pembelajaran, sedangkan dari segi hasil, apabila $85 \%$ anak memperoleh nilai berkembang sesuai harapan (BSH) atau dengan simbol *** dan berkembang sangat baik (BSB) atau dengan simbol ****, maka dapat dikatakan peningkatan kemampuan motorik halus melalui kegiatan kelas telah berhasil.

\section{HASIL DAN PEMBAHASAN}

$\begin{array}{crr}\text { Sebelum } & \text { kegiatan } & \text { penelitian } \\ \text { dilaksanakan, } & \text { terlebih dahulu peneliti }\end{array}$ melakukan diskusi dengan guru kelompok B1 tentang kegiatan penelitian yang akan dilakukan peneliti yaitu, penerapan kegiatan memasak untuk meningkatkan kemampuan motorik halus anak. Berdasarkan hasil observasi awal dan wawancara singkat yang dilakukan menunjukan bahwa kemampuan motorik halus anak pada kelompok B1 RA Wildaanun Rabbaniyyun Kendari masih perlu dikembangkan dan ditingkatkan lagi. Kurang meningkatnya kemampuan motorik halus anak diduga disebabkan masih kurangnya media yang tepat dalam kegiatan pembelajaran meningkatkan kemampuan motorik halus anak sehingga proses pembelajaran menjadi kurang efektif. Untuk membuktikan hasil pengamatan tersebut, sebelum dilaksanakan tindakan penelitian kelas maka peneliti mengamati secara langsung kegiatan pembelajaran dalam meningkatkan kemampuan motorik halus anak di kelompok B1 RA Wildaanun Rabbaniyyun Kendari.

Pelaksanaan tindakan siklus I pertemuan I dilaksanakan dengan kegiatan inti guru memberikan apersepsi yaitu memberikan gambaran tentang kegiatan kelas memasak yang akan dilakukan hari ini, serta menunjukkan langsung kegiatan membuat minuman melalui kegiatan kelas memasak. Adapun kegiatan yang dilakukan oleh anak yaitu menyebutkan alat-alat apa saja yang digunakan dalam kegiatan kelas memasak, mengamati guru mendemonstrasikan kegiatan kelas memasak membuat susu dan cara mengaduknya. Kemudian anak mendemonstrasikan kegiatan kelas memasak membuat susu dan mengaduk sebagaimana contoh, menunjukkan hasil karya masingmasing pada guru kemudian anak-anak menikmati hasil dari kegiatan memasak masingmasing, dan anak menceritakan tentang kegiatan 
kelas memasak yang telah dilakukan dan dirasakan.

Pada pertemuan pertama, hasil kerja anak dapat diuraikan sebagai berikut: anak yang mendapat nilai kategori BSB (Berkembang Sangat Baik) yaitu anak yang sudah dapat melakukan indikator kinerja secara mandiri dan konsisten tanpa diingatkan atau dicontohkan oleh guru saat kegiatan berlangsung. Anak yang mendapat nilai kategori BSH (Berkembang Sesuai Harapan) yaitu anak yang sudah dapat melakukan indikator kinerja secara mandiri dan masih diingatkan oleh guru ketika lupa bagaimana cara menggunakannya. Anak yang mendapat nilai kategori MB (Mulai Berkembang) yaitu anak yang sudah dapat melakukan indikator kinerja dengan cara diingatkan guru atau dibantu oleh guru. Anak yang mendapat nilai kategori BB (Belum Berkembang) yaitu anak yang tidak dapat berbuat atau tidak mau berbuat dan memerlukan bantuan atau contoh dari guru dari awal kegiatan hingga akhir kegiatan.

Pada siklus I pertemuan I, dari 15 orang anak didik terdapat 2 orang anak didik (ASM dan AUR) yang mendapat nilai BSB yaitu anak dapat memotong, mengaduk, menguleni dan membentuk bahan yang digunakan saat kegiatan kelas memasak secara mandiri dan konsisten tanpa diingatkan atau dicontohkan oleh guru saat kegiatan berlangsung; terdapat 5 orang anak didik (HIL, ATA, SYA, AFI dan HAN) yang mendapat nilai BSH yaitu anak dapat memotong, mengaduk, menguleni dan membentuk bahan yang digunakan saat kegiatan kelas memasak secara mandiri dan dan masih diingatkan oleh guru ketika lupa bagaimana cara menggunakannya; terdapat 6 orang anak didik (RAY, FAD, TYA, NID, IFA dan IZU) yang mendapat nilai kategori MB yaitu anak dapat memotong, mengaduk, menguleni dan membentuk bahan yang digunakan saat kegiatan kelas memasak dengan cara diingatkan, dibimbing atau dicontohkan guru; terdapat 2 orang anak didik (AZ dan ALF) yang mendapat nilai BB yaitu anak yang tidak dapat memotong, mengaduk, menguleni dan membentuk bahan yang digunakan saat kegiatan kelas memasak dan memerlukan bimbingan atau dicontohkan oleh guru dari awal hingga akhir kegiatan berlangsung.

Pada kegiatan akhir dimana guru mempersilahkan anak untuk duduk kembali dan mengarahkan anak untuk berdoa sebelum makan setelah selesai berdoa anak-anak diarahkan untuk mencuci tangan terlebih dahulu kemudian anak makan bersama temannya. Setelah selesai makan anak merapikan tempat makannya dan kembali mencuci tangan dan membaca doa sesudah makan. Setelah selesai, guru melakukan tanya jawab tentang kegiatan yang telah dilakukan. Guru memberikan informasi tentang kegiatan yang akan dilakukan besok, guru mempersiapkan anak untuk pulang dan guru membimbing anak untuk mengucapkan doa keselamatan dan doa pulang sekolah dan di akhiri dengan ucapan salam.

Pelaksanaan tindakan siklus I pertemuan II dilaksanakan dengan kegiatan inti guru memberikan apersepsi yaitu memberikan gambaran tentang kegiatan kelas memasak yang akan dilakukan hari ini, serta menunjukkan langsung kegiatan membuat minuman dengan kegiatan kelas memasak. Adapun kegiatan yang dilakukan oleh anak yaitu menyebutkan alat-alat apa saja yang digunakan dalam kegiatan kelas memasak, mengamati guru mendemonstrasikan kegiatan kelas memasak membuat teh dan cara mengaduknya. Kemudian anak mendemonstrasikan kegiatan kelas memasak membuat teh dan mengaduk sebagaimana contoh, menunjukkan hasil karya masingmasing pada guru kemudian anak-anak menikmati hasil dari kegiatan memasak masingmasing, dan anak menceritakan tentang kegiatan kelas memasak yang telah dilakukan dan dirasakan.

Pada pertemuan kedua, hasil kerja anak dapat diuraikan sebagai berikut: anak yang mendapat nilai kategori BSB (Berkembang Sangat Baik) yaitu anak yang sudah dapat melakukan indikator kinerja secara mandiri dan konsisten tanpa diingatkan atau dicontohkan oleh guru saat kegiatan berlangsung diantaranya. Anak yang mendapat nilai kategori BSH (Berkembang Sesuai Harapan) yaitu anak yang sudah dapat melakukan indikator kinerja secara mandiri dan masih diingatkan oleh guru ketika lupa bagaimana cara menggunakannya. Anak yang mendapat nilai kategori MB (Mulai Berkembang) yaitu anak yang sudah dapat melakukan indikator kinerja dengan cara diingatkan guru atau dibantu oleh guru. Anak yang mendapat nilai kategori BB (Belum Berkembang) yaitu anak yang tidak dapat berbuat atau tidak mau berbuat dan memerlukan bantuan atau contoh dari guru dari awal kegiatan hingga akhir kegiatan.

Pada siklus I pertemuan II, dari 15 orang anak didik terdapat 4 orang anak didik (ASM, AUR, AFI, HAN) yang mendapat nilai BSB yaitu anak dapat memotong, mengaduk, 
menguleni dan membentuk bahan yang digunakan saat kegiatan kelas memasak secara mandiri dan konsisten tanpa diingatkan atau dicontohkan oleh guru saat kegiatan berlangsung; terdapat 5 orang anak didik (HIL, ATA, SYA, TYA, IFA) yang mendapat nilai BSH yaitu anak dapat memotong, mengaduk, menguleni dan membentuk bahan yang digunakan saat kegiatan kelas memasak secara mandiri dan dan masih diingatkan oleh guru ketika lupa bagaimana cara menggunakannya; terdapat 4 orang anak didik (RAY, FAD, NID, IZU) yang mendapat nilai kategori MB yaitu anak dapat memotong, mengaduk, menguleni dan membentuk bahan yang digunakan saat kegiatan kelas memasak dengan cara diingatkan, dibimbing atau dicontohkan guru; terdapat 2 orang anak didik (AZ dan ALF) yang mendapat nilai BB yaitu anak yang tidak dapat memotong, mengaduk, menguleni dan membentuk bahan yang digunakan saat kegiatan kelas memasak dan memerlukan bimbingan atau dicontohkan oleh guru dari awal hingga akhir kegiatan berlangsung.

Pada kegiatan akhir dimana guru mempersilahkan anak untuk duduk kembali dan mengarahkan anak untuk berdoa sebelum makan setelah selesai berdoa anak-anak diarahkan untuk mencuci tangan terlebih dahulu kemudian anak makan bersama temannya. Setelah selesai makan anak merapikan tempat makannya dan kembali mencuci tangan dan membaca doa sesudah makan. Setelah selesai, guru melakukan tanya jawab tentang kegiatan yang telah dilakukan. Guru memberikan informasi tentang kegiatan yang akan dilakukan besok, guru mempersiapkan anak untuk pulang dan guru membimbing anak untuk mengucapkan doa keselamatan dan doa pulang sekolah dan di akhiri dengan ucapan salam.

Pelaksanaan tindakan siklus I petemuan III dilaksanakan dengan kegiatan inti guru memberikan apersepsi yaitu memberikan gambaran tentang kegiatan kelas memasak yang akan dilakukan hari ini, serta menunjukkan langsung kegiatan membuat minuman dengan kegiatan kelas memasak. Adapun kegiatan yang dilakukan oleh anak yaitu menyebutkan alat-alat apa saja yang digunakan dalam kegiatan kelas memasak, mengamati guru mendemonstrasikan kegiatan kelas memasak membuat sirup dan cara mengaduknya. Kemudian anak mendemonstrasikan kegiatan kelas memasak membuat sirup dan mengaduk sebagaimana contoh, menunjukkan hasil karya masingmasing pada guru kemudian anak-anak menikmati hasil dari kegiatan memasak masingmasing, dan anak menceritakan tentang kegiatan kelas memasak yang telah dilakukan dan dirasakan.

Pada pertemuan ketiga, hasil kerja anak dapat diuraikan sebagai berikut: anak yang mendapat nilai kategori BSB (Berkembang Sangat Baik) yaitu anak yang sudah dapat melakukan indikator kinerja secara mandiri dan konsisten tanpa diingatkan atau dicontohkan oleh guru saat kegiatan berlangsung. Anak yang mendapat nilai kategori BSH (Berkembang Sesuai Harapan) yaitu anak yang sudah dapat melakukan indikator kinerja secara mandiri dan masih diingatkan oleh guru ketika lupa bagaimana cara menggunakannya. Anak yang mendapat nilai kategori MB (Mulai Berkembang) yaitu anak yang sudah dapat melakukan indikator kinerja dengan cara diingatkan guru atau dibantu oleh guru. Anak yang mendapat nilai kategori BB (Belum Berkembang) yaitu anak yang tidak dapat berbuat atau tidak mau berbuat dan memerlukan bantuan atau contoh dari guru dari awal kegiatan hingga akhir kegiatan.

Pada siklus I pertemuan III, dari 15 orang anak didik terdapat 6 orang anak didik (ASM, AUR, AFI, HAN, ATA, HIL) yang mendapat nilai BSB yaitu anak dapat memotong, mengaduk, menguleni dan membentuk bahan yang digunakan saat kegiatan kelas memasak secara mandiri dan konsisten tanpa diingatkan atau dicontohkan oleh guru saat kegiatan berlangsung; terdapat 4 orang anak didik (SYA, TYA, IFA,IZU) yang mendapat nilai BSH yaitu anak dapat memotong, mengaduk, menguleni dan membentuk bahan yang digunakan saat kegiatan kelas memasak secara mandiri dan dan masih diingatkan oleh guru ketika lupa bagaimana cara menggunakannya; terdapat 4 orang anak didik (RAY, FAD, NID, AZ) yang mendapat nilai kategori MB yaitu anak dapat memotong, mengaduk, menguleni dan membentuk bahan yang digunakan saat kegiatan kelas memasak dengan cara diingatkan, dibimbing atau dicontohkan guru; terdapat 1 orang anak didik (ALF) yang mendapat nilai BB yaitu anak yang tidak dapat memotong, mengaduk, menguleni dan membentuk bahan yang digunakan saat kegiatan kelas memasak dan memerlukan bimbingan atau dicontohkan oleh guru dari awal hingga akhir kegiatan berlangsung.

Pada kegiatan akhir dimana guru mempersilahkan anak untuk duduk kembali dan mengarahkan anak untuk berdoa sebelum makan 
setelah selesai berdoa anak-anak diarahkan untuk mencuci tangan terlebih dahulu kemudian anak makan bersama temannya. Setelah selesai makan anak merapikan tempat makannya dan kembali mencuci tangan dan membaca doa sesudah makan. Setelah selesai, guru melakukan tanya jawab tentang kegiatan yang telah dilakukan. Guru memberikan informasi tentang kegiatan yang akan dilakukan besok, guru mempersiapkan anak untuk pulang dan guru membimbing anak untuk mengucapkan doa keselamatan dan doa pulang sekolah dan di akhiri dengan ucapan salam.

Pelasanaan tindakan siklus I pertemuan IV dilaksanakn dengan kegiatan inti guru memberikan apersepsi yaitu memberikan gambaran tentang kegiatan kelas memasak yang akan dilakukan hari ini, serta menunjukkan langsung kegiatan membuat minuman dengan kegiatan kelas memasak. Adapun kegiatan yang dilakukan oleh anak yaitu menyebutkan alat-alat apa saja yang digunakan dalam kegiatan kelas memasak, mengamati guru mendemonstrasikan kegiatan kelas memasak membuat jus mangga dan cara mengaduknya. Kemudian anak mendemonstrasikan kegiatan kelas memasak membuat jus mangga dan mengaduk sebagaimana contoh, menunjukkan hasil karya masing-masing pada guru kemudian anak-anak menikmati hasil dari kegiatan memasak masingmasing, dan anak menceritakan tentang kegiatan kelas memasak yang telah dilakukan dan dirasakan.

Pada pertemuan keempat, hasil kerja anak dapat diuraikan sebagai berikut: anak yang mendapat nilai kategori BSB (Berkembang Sangat Baik) yaitu anak yang sudah dapat melakukan indikator kinerja secara mandiri dan konsisten tanpa diingatkan atau dicontohkan oleh guru saat kegiatan berlangsung. Anak yang mendapat nilai kategori BSH (Berkembang Sesuai Harapan) yaitu anak yang sudah dapat melakukan indikator kinerja secara mandiri dan masih diingatkan oleh guru ketika lupa bagaimana cara menggunakannya. Anak yang mendapat nilai kategori MB (Mulai Berkembang) yaitu anak yang sudah dapat melakukan indikator kinerja dengan cara diingatkan guru atau dibantu oleh guru. Anak yang mendapat nilai kategori BB (Belum Berkembang) yaitu anak yang tidak dapat berbuat atau tidak mau berbuat dan memerlukan bantuan atau contoh dari guru dari awal kegiatan hingga akhir kegiatan.

Pada siklus I pertemuan IV, dari 15 orang anak didik terdapat 7 orang anak didik (ASM,
AUR, AFI, HAN, ATA, HIL, SYA) yang mendapat nilai BSB yaitu anak dapat memotong, mengaduk, menguleni dan membentuk bahan yang digunakan saat kegiatan kelas memasak secara mandiri dan konsisten tanpa diingatkan atau dicontohkan oleh guru saat kegiatan berlangsung; terdapat 4 orang anak didik (TYA, IFA, IZU, NID) yang mendapat nilai BSH yaitu anak dapat memotong, mengaduk, menguleni dan membentuk bahan yang digunakan saat kegiatan kelas memasak secara mandiri dan dan masih diingatkan oleh guru ketika lupa bagaimana cara menggunakannya; terdapat 3 orang anak didik (RAY, FAD, AZ) yang mendapat nilai kategori MB yaitu anak dapat memotong, mengaduk, menguleni dan membentuk bahan yang digunakan saat kegiatan kelas memasak dengan cara diingatkan, dibimbing atau dicontohkan guru; terdapat 1 orang anak didik (ALF) yang mendapat nilai BB yaitu anak yang tidak dapat memotong, mengaduk, menguleni dan membentuk bahan yang digunakan saat kegiatan kelas memasak dan memerlukan bimbingan atau dicontohkan oleh guru dari awal hingga akhir kegiatan berlangsung.

Pada kegiatan akhir dimana guru mempersilahkan anak untuk duduk kembali dan mengarahkan anak untuk berdoa sebelum makan setelah selesai berdoa anak-anak diarahkan untuk mencuci tangan terlebih dahulu kemudian anak makan bersama temannya. Setelah selesai makan anak merapikan tempat makannya dan kembali mencuci tangan dan membaca doa sesudah makan. Setelah selesai, guru melakukan tanya jawab tentang kegiatan yang telah dilakukan. Guru memberikan informasi tentang kegiatan yang akan dilakukan besok, guru mempersiapkan anak untuk pulang dan guru membimbing anak untuk mengucapkan doa keselamatan dan doa pulang sekolah dan di akhiri dengan ucapan salam.

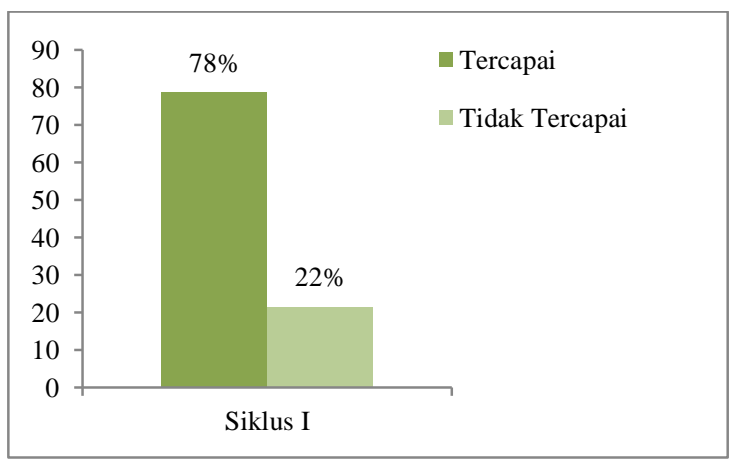

Gambar 1. Diagram Hasil Analisis Aktivitas Mengajar Guru Siklus I 
Hasil observasi mengajar guru pada siklus I ini sesuai dengan pedoman lembar obsevasi sebanyak 14 aspek yang diamati dan akan dicapai oleh guru. Pada siklus I skor yang dicapai oleh guru dari 14 aspek hanya 11 aspek setara dengan $78 \%$. Aspek yang diamati diantaranya yaitu: (1) guru mempersiapkan anak untuk belajar dan membuka pembelajaran dengan kegiatan imtaq, (2) guru menyiapkan alat dan bahan pembelajaran, (3) guru menyampaikan tujuan pembelajaran, (4) guru menjelaskan materi pembelajaran yang akan dilaksanakan, (5) guru memperlihatkan mediamedia yang akan digunakan dalam kegiatan kelas memasak, (6) guru meminta anak untuk memperhatikan dan menyebutkan gambar yang di tunjukkan, (7) guru memperlihatkan alat-alat yang digunakan dalam kegiatan kelas memasak, (8) guru memberikan 2 pertanyaan sederhana kepada anak tentang pembelajaran yang akan dilaksanakan, (9) guru meminta anak untuk menyebutkan apa saja alat-alat yang digunakan dalam kegiatan kelas memasak, (10) guru membimbing dan mengawasi anak dalam proses pembelajaran kegiatan memasak, (11) guru meminta anak mendemonstrasikan kegiatan kelas memasak sesuai yang telah dicontohkan guru, (12) guru melakukan proses recall atau mengingatkan kembali apa-apa yang telah dilakukan, (13) guru memberikan reward atau pujian kepada anak, (14) guru memberikan kesimpulan tentang pembelajaran yang telah dilakukan. Sedangkan aspek yang tidak tercapai sebanyak 3 aspek dengan persentase 22\% diantaranya yaitu: (1) guru menyampaikan tujuan pembelajaran, (2) guru memberikan reward atau pujian kepada anak, (3) guru memberikan kesimpulan tentang pembelajaran yang telah dilakukan.

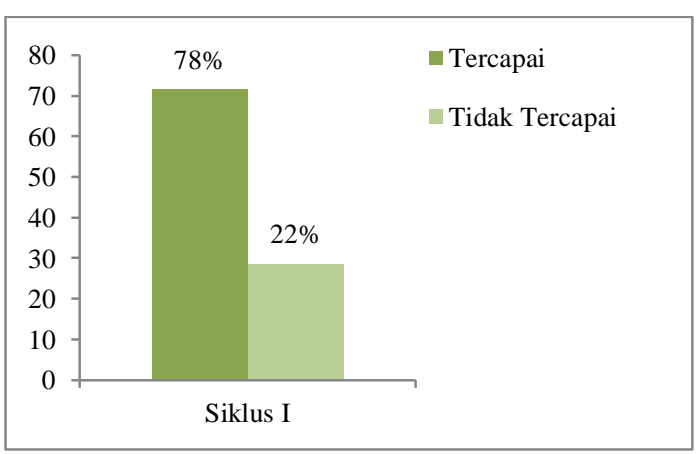

Gambar 2. Diagram Hasil Analisis Aktivitas Belajar Anak Didik Siklus I

Hasil analisis proses pembelajaran Siklus I aktivitas belajar anak yang diamati menggunakan lembar observasi aktivitas belajar anak terdiri atas 14 aspek yang diamati dan akan dicapai oleh anak. Pada siklus I skor yang dicapai oleh anak dari 14 aspek hanya 11 aspek setara dengan 78\%. Aspek yang diamati diantaranya yaitu: (1) anak siap untuk belajar dan mengawali pembelajaran dengan kegiatan imtaq, (2) anak memperoleh alat dan bahan pembelajaran, (3) anak menyebutkan tujuan pembelajaran, (4) anak menyebutkan kembali materi pembelajaran yang akan dilaksanakan, (5) anak menyebutkan media-media yang akan digunakan dalam kegiatan kelas memasak, (6) anak memperhatikan dan menyebutkan gambar yang di tunjukkan, (7) anak memperlihatkan alat-alat yang akan digunakan dalam kegiatan kelas memasak, (8) anak menjawab 2 pertanyaan sederhana dari guru tentang pembelajaran yang dilaksanakan, (9) anak menyebutkan alat-alat yang digunakan dalam kegiatan kelas memasak, (10) anak memperoleh bimbingan dalam proses pembelajaran kegiatan memasak, (11) anak mendemonstrasikan kegiatan kelas memasak sesuai yang telah dicontohkan guru, (12) anak menyebutkan kembali apa-apa yang telah dilakukan, (13) anak memperoleh reward atau pujian dari guru, (14) anak menyebutkan kesimpulan tentang pembelajaran yang telah dilakukan. Sedangkan aspek yang tidak tercapai sebanyak 3 aspek dengan persentase $22 \%$ diantaranya yaitu: (1) anak menyebutkan tujuan pembelajaran, (2) anak memperoleh reward atau pujian dari guru, (3) anak menyebutkan kesimpulan tentang pembelajaran yang telah dilakukan.

Tabel 2. Nilai Klasikal pada Siklus I

\begin{tabular}{lcc}
\hline \multicolumn{1}{c}{ Kategori } & Jumlah & $\mathbf{( \% )}$ \\
\hline $\begin{array}{l}\text { Berkembang Sangat } \\
\text { Baik }\end{array}$ & 7 & $47 \%$ \\
\hline $\begin{array}{l}\text { Berkembang Sesuai } \\
\text { Harapan }\end{array}$ & 4 & $27 \%$ \\
\hline Mulai Berkembang & 3 & $20 \%$ \\
\hline Belum Berkembang & 1 & $6 \%$ \\
\hline \multicolumn{1}{c}{ Jumlah } & 15 & $100 \%$ \\
\hline
\end{tabular}

Berdasarkan hasil yang diperoleh pada tabel 2, terlihat bahwa secara klasikal kegiatan meningkatkan kemampuan motorik halus anak melalui kegiatan kelas memasak sebagian besar anak sudah dapat melaksanakan kegiatan dengan baik yaitu $74 \%$. Anak yang memperoleh bintang (****) atau Berkembang Sangat Baik (BSB) yaitu 7 orang anak didik dengan persentase $47 \%$, nilai bintang (***) atau Berkembang Sesuai Harapan (BSH) yaitu sebanyak 4 orang anak dengan peresentase 27\%. Anak yang 
memperoleh nilai bintang (**) atau Mulai Berkembang (MB) yaitu sebanyak 3 orang anak didik dengan persentase 20\%. Anak yang memperoleh nilai bintang (*) atau Belum Berkembang Berkembang (MB) yaitu sebanyak 3 orang anak didik dengan persentase $6 \%$. Hal ini sejalan dengan hasil penelitian (Laely \& Subiyanto, 2020) yang menunjukkan bahwa implementasi kelas memasak mampu meningkatkan kemampuan motorik halus anak usia dini.

Berdasarkan hasil evaluasi, sebagian besar anak didik sudah dapat melaksanakan kegiatan memasak dengan baik. Hal ini tentu saja akan dihubungkan dengan indikator kinerja yang ditetapkan yaitu jika anak didik mencapai tingkat perolehan nilai keberhasilan sebesar $85 \%$. Hal ini sejalan dengan (Darwati, Wijayanti, \& Azizah, 2019) yang mengatakan bahwa kegiatn memasak dapat meningkatkan kemampuan motorik halus anak sebesar $80 \%$. Tindakan siklus I hanya mencapai perolehan nilai sebesar $74 \%$, maka dapat dikatakan bahwa pelaksanaan penelitian tindakan ini belum terselesaikan dan hal ini akan dilanjutkan pada tahapan siklus selajutnya yaitu siklus II.

Berdasarkan hasil observasi, maka beberapa hal yang harus diperbaiki adalah kurangnya kemampuan peneliti dalam mengelola kelas, peneliti kurang aktif dalam melakukan tanya jawab dengan anak, peneliti masih kurang dalam memyampaikan tujuan pembelajaran yang dilakukan, sehingga kegiatan penelitian dilanjutkan pada Siklus II.

Pelaksanaan tindakan siklus II pertemuan I dilaksanakan dengan kegiatan inti guru memberikan apersepsi yaitu memberikan gambaran tentang kegiatan kelas memasak yang akan dilakukan hari ini, serta menunjukkan langsung kegiatan membuat makanan dengan kegiatan kelas memasak. Adapun kegiatan yang dilakukan oleh anak yaitu menyebutkan alat-alat apa saja yang digunakan dalam kegiatan kelas memasak, mengamati guru mendemonstrasikan kegiatan kelas memasak membuat roti bakar dan cara membentuk roti segi tiga dan persegi panjang. Kemudian anak mendemonstrasikan kegiatan kelas memasak membuat roti bakar dan cara membentuk roti segi tiga dan persegi panjang sebagaimana contoh, menunjukkan hasil karya masing-masing pada guru kemudian anak-anak menikmati hasil dari kegiatan memasak masing-masing, dan anak menceritakan tentang kegiatan kelas memasak yang telah dilakukan dan dirasakan.
Pada pertemuan pertama, hasil kerja anak dapat diuraikan sebagai berikut: anak yang mendapat nilai kategori BSB (Berkembang Sangat Baik) yaitu anak yang sudah dapat melakukan indikator kinerja secara mandiri dan konsisten tanpa diingatkan atau dicontohkan oleh guru saat kegiatan berlangsung. Anak yang mendapat nilai kategori BSH (Berkembang Sesuai Harapan) yaitu anak yang sudah dapat melakukan indikator kinerja secara mandiri dan masih diingatkan oleh guru ketika lupa bagaimana cara menggunakannya. Anak yang mendapat nilai kategori MB (Mulai Berkembang) yaitu anak yang sudah dapat melakukan indikator kinerja dengan cara diingatkan guru atau dibantu oleh guru. Anak yang mendapat nilai kategori BB (Belum Berkembang) yaitu anak yang tidak dapat berbuat atau tidak mau berbuat dan memerlukan bantuan atau contoh dari guru dari awal kegiatan hingga akhir kegiatan.

Pada siklus II pertemuan I, dari 15 orang anak didik terdapat 7 orang anak didik (ASM, AUR, AFI, HAN, ATA, HIL, SYA) yang mendapat nilai BSB yaitu anak dapat memotong, mengaduk, menguleni dan membentuk bahan yang digunakan saat kegiatan kelas memasak secara mandiri dan konsisten tanpa diingatkan atau dicontohkan oleh guru saat kegiatan berlangsung; terdapat 4 orang anak didik (TYA, IFA, IZU, NID) yang mendapat nilai BSH yaitu anak dapat memotong, mengaduk, menguleni dan membentuk bahan yang digunakan saat kegiatan kelas memasak secara mandiri dan dan masih diingatkan oleh guru ketika lupa bagaimana cara menggunakannya; terdapat 3 orang anak didik (RAY, FAD, AZ) yang mendapat nilai kategori MB yaitu anak dapat memotong, mengaduk, menguleni dan membentuk bahan yang digunakan saat kegiatan kelas memasak dengan cara diingatkan, dibimbing atau dicontohkan guru; terdapat 1 orang anak didik (ALF) yang mendapat nilai BB yaitu anak yang tidak dapat memotong, mengaduk, menguleni dan membentuk bahan yang digunakan saat kegiatan kelas memasak dan memerlukan bimbingan atau dicontohkan oleh guru dari awal hingga akhir kegiatan berlangsung.

Pada kegiatan akhir dimana guru mempersilahkan anak untuk duduk kembali dan mengarahkan anak untuk berdoa sebelum makan setelah selesai berdoa anak-anak diarahkan untuk mencuci tangan terlebih dahulu kemudian anak makan bersama temannya. Setelah selesai makan anak merapikan tempat makannya dan 
kembali mencuci tangan dan membaca doa sesudah makan. Setelah selesai, guru melakukan tanya jawab tentang kegiatan yang telah dilakukan. Guru memberikan informasi tentang kegiatan yang akan dilakukan besok, guru mempersiapkan anak untuk pulang dan guru membimbing anak untuk mengucapkan doa keselamatan dan doa pulang sekolah dan di akhiri dengan ucapan salam.

Pelaksanaan tindakan siklus II pertemuan II dilaksanakan dengan kegiatan inti guru memberikan apersepsi yaitu memberikan gambaran tentang kegiatan kelas memasak yang akan dilakukan hari ini, serta menunjukkan langsung kegiatan membuat makanan dengan kegiatan kelas memasak. Adapun kegiatan yang dilakukan oleh anak yaitu menyebutkan alat-alat apa saja yang digunakan dalam kegiatan kelas memasak, mengamati guru mendemonstrasikan kegiatan kelas memasak membuat sate buah dan cara memotong. Kemudian anak mendemonstrasikan kegiatan kelas memasak membuat sate buah dan cara memotong sebagaimana contoh, menunjukkan hasil karya masing-masing pada guru kemudian anak-anak menikmati hasil dari kegiatan memasak masingmasing, dan anak menceritakan tentang kegiatan kelas memasak yang telah dilakukan dan dirasakan.

Pada pertemuan kedua, hasil kerja anak dapat diuraikan sebagai berikut: anak yang mendapat nilai kategori BSB (Berkembang Sangat Baik) yaitu anak yang sudah dapat melakukan indikator kinerja secara mandiri dan konsisten tanpa diingatkan atau dicontohkan oleh guru saat kegiatan berlangsung. Anak yang mendapat nilai kategori BSH (Berkembang Sesuai Harapan) yaitu anak yang sudah dapat melakukan indikator kinerja secara mandiri dan masih diingatkan oleh guru ketika lupa bagaimana cara menggunakannya. Anak yang mendapat nilai kategori MB (Mulai Berkembang) yaitu anak yang sudah dapat melakukan indikator kinerja dengan cara diingatkan guru atau dibantu oleh guru. Anak yang mendapat nilai kategori BB (Belum Berkembang) yaitu anak yang tidak dapat berbuat atau tidak mau berbuat dan memerlukan bantuan atau contoh dari guru dari awal kegiatan hingga akhir kegiatan.

Pada siklus II pertemuan II, dari 15 orang anak didik terdapat 9 orang anak didik (ASM, AUR, AFI, HAN, ATA, HIL, SYA, NID, IFA) yang mendapat nilai BSB yaitu anak dapat memotong, mengaduk, menguleni dan membentuk bahan yang digunakan saat kegiatan kelas memasak secara mandiri dan konsisten tanpa diingatkan atau dicontohkan oleh guru saat kegiatan berlangsung; terdapat 4 orang anak didik (TYA, IZU, FAD, AZ) yang mendapat nilai BSH yaitu anak dapat memotong, mengaduk, menguleni dan membentuk bahan yang digunakan saat kegiatan kelas memasak secara mandiri dan dan masih diingatkan oleh guru ketika lupa bagaimana cara menggunakannya; terdapat 2 orang anak didik (RAY, ALF) yang mendapat nilai kategori MB yaitu anak dapat memotong, mengaduk, menguleni dan membentuk bahan yang digunakan saat kegiatan kelas memasak dengan cara diingatkan, dibimbing atau dicontohkan guru.

Pada kegiatan akhir dimana guru mempersilahkan anak untuk duduk kembali dan mengarahkan anak untuk berdoa sebelum makan setelah selesai berdoa anak-anak diarahkan untuk mencuci tangan terlebih dahulu kemudian anak makan bersama temannya. Setelah selesai makan anak merapikan tempat makannya dan kembali mencuci tangan dan membaca doa sesudah makan. Setelah selesai, guru melakukan tanya jawab tentang kegiatan yang telah dilakukan. Guru memberikan informasi tentang kegiatan yang akan dilakukan besok, guru mempersiapkan anak untuk pulang dan guru membimbing anak untuk mengucapkan doa keselamatan dan doa pulang sekolah dan diakhiri dengan ucapan salam.

Pelaksanaan tindakah siklus II pertemuan III dilaksanakan dengan kegiatan inti guru memberikan apersepsi yaitu memberikan gambaran tentang kegiatan kelas memasak yang akan dilakukan hari ini, serta menunjukkan langsung kegiatan membuat makanan dengan kegiatan kelas memasak. Adapun kegiatan yang dilakukan oleh anak yaitu menyebutkan alat-alat apa saja yang digunakan dalam kegiatan kelas memasak, mengamati guru mendemonstrasikan kegiatan kelas memasak membuat bola-bola coklat dan cara membuatnya. Kemudian anak mendemonstrasikan kegiatan kelas memasak membuat bola-bola coklat dan cara membuatnya sebagaimana contoh, menunjukkan hasil karya masing-masing pada guru kemudian anak-anak menikmati hasil dari kegiatan memasak masingmasing, dan anak menceritakan tentang kegiatan kelas memasak yang telah dilakukan dan dirasakan.

Pada pertemuan ketiga, hasil kerja anak dapat diuraikan sebagai berikut: anak yang mendapat nilai kategori BSB (Berkembang Sangat Baik) yaitu anak yang sudah dapat 
melakukan indikator kinerja secara mandiri dan konsisten tanpa diingatkan atau dicontohkan oleh guru saat kegiatan berlangsung. Anak yang mendapat nilai kategori BSH (Berkembang Sesuai Harapan) yaitu anak yang sudah dapat melakukan indikator kinerja secara mandiri dan masih diingatkan oleh guru ketika lupa bagaimana cara menggunakannya. Anak yang mendapat nilai kategori MB (Mulai Berkembang) yaitu anak yang sudah dapat melakukan indikator kinerja dengan cara diingatkan guru atau dibantu oleh guru. Anak yang mendapat nilai kategori BB (Belum Berkembang) yaitu anak yang tidak dapat berbuat atau tidak mau berbuat dan memerlukan bantuan atau contoh dari guru dari awal kegiatan hingga akhir kegiatan.

Pada siklus II pertemuan III, dari 15 orang anak didik terdapat 10 orang anak didik (ASM, AUR, AFI, HAN, ATA, HIL, SYA, NID, IFA, TYA) yang mendapat nilai BSB yaitu anak dapat memotong, mengaduk, menguleni dan membentuk bahan yang digunakan saat kegiatan kelas memasak secara mandiri dan konsisten tanpa diingatkan atau dicontohkan oleh guru saat kegiatan berlangsung; terdapat 3 orang anak didik (IZU, FAD, AZ) yang mendapat nilai BSH yaitu anak dapat memotong, mengaduk, menguleni dan membentuk bahan yang digunakan saat kegiatan kelas memasak secara mandiri dan dan masih diingatkan oleh guru ketika lupa bagaimana cara menggunakannya; terdapat 2 orang anak didik (RAY, ALF) yang mendapat nilai kategori MB yaitu anak dapat memotong, mengaduk, menguleni dan membentuk bahan yang digunakan saat kegiatan kelas memasak dengan cara diingatkan, dibimbing atau dicontohkan guru.

Pada kegiatan akhir dimana guru mempersilahkan anak untuk duduk kembali dan mengarahkan anak untuk berdoa sebelum makan setelah selesai berdoa anak-anak diarahkan untuk mencuci tangan terlebih dahulu kemudian anak makan bersama temannya. Setelah selesai makan anak merapikan tempat makannya dan kembali mencuci tangan dan membaca doa sesudah makan. Setelah selesai, guru melakukan tanya jawab tentang kegiatan yang telah dilakukan. Guru memberikan informasi tentang kegiatan yang akan dilakukan besok, guru mempersiapkan anak untuk pulang dan guru membimbing anak untuk mengucapkan doa keselamatan dan doa pulang sekolah dan di akhiri dengan ucapan salam.

Pelaksanaan tindakan siklus II pertemuan IV dilaksanakan dengan kegiatan inti guru memberikan apersepsi yaitu memberikan gambaran tentang kegiatan kelas memasak yang akan dilakukan hari ini, serta menunjukkan langsung kegiatan membuat makanan dengan kegiatan kelas memasak. Adapun kegiatan yang dilakukan oleh anak yaitu menyebutkan alat-alat apa saja yang digunakan dalam kegiatan kelas memasak, mengamati guru mendemonstrasikan kegiatan kelas memasak membuat bola-bola ubi dan cara membentuknya. Kemudian anak mendemonstrasikan kegiatan kelas memasak membuat bola-bola ubi dan cara membentuknya sebagaimana contoh, menunjukkan hasil karya masing-masing pada guru kemudian anak-anak menikmati hasil dari kegiatan memasak masingmasing, dan anak menceritakan tentang kegiatan kelas memasak yang telah dilakukan dan dirasakan.

Pada pertemuan keempat, hasil kerja anak dapat diuraikan sebagai berikut: anak yang mendapat nilai kategori BSB (Berkembang Sangat Baik) yaitu anak yang sudah dapat melakukan indikator kinerja secara mandiri dan konsisten tanpa diingatkan atau dicontohkan oleh guru saat kegiatan berlangsung. Anak yang mendapat nilai kategori BSH (Berkembang Sesuai Harapan) yaitu anak yang sudah dapat melakukan indikator kinerja secara mandiri dan masih diingatkan oleh guru ketika lupa bagaimana cara menggunakannya. Anak yang mendapat nilai kategori MB (Mulai Berkembang) yaitu anak yang sudah dapat melakukan indikator kinerja dengan cara diingatkan guru atau dibantu oleh guru. Anak yang mendapat nilai kategori BB (Belum Berkembang) yaitu anak yang tidak dapat berbuat atau tidak mau berbuat dan memerlukan bantuan atau contoh dari guru dari awal kegiatan hingga akhir kegiatan.

Pada siklus II pertemuan IV, dari 15 orang anak didik terdapat 11 orang anak didik (ASM, AUR, AFI, HAN, ATA, HIL, SYA, NID, IFA, TYA, IZU) yang mendapat nilai BSB yaitu anak dapat memotong, mengaduk, menguleni dan membentuk bahan yang digunakan saat kegiatan kelas memasak secara mandiri dan konsisten tanpa diingatkan atau dicontohkan oleh guru saat kegiatan berlangsung; terdapat 2 orang anak didik (FAD, AZ) yang mendapat nilai BSH yaitu anak dapat memotong, mengaduk, menguleni dan membentuk bahan yang digunakan saat kegiatan kelas memasak secara mandiri dan dan masih diingatkan oleh guru ketika lupa bagaimana cara menggunakannya; terdapat 2 orang anak didik (RAY, ALF) yang mendapat nilai kategori MB 
yaitu anak dapat memotong, mengaduk, menguleni dan membentuk bahan yang digunakan saat kegiatan kelas memasak dengan cara diingatkan, dibimbing atau dicontohkan guru.

Pada kegiatan akhir dimana guru mempersilahkan anak untuk duduk kembali dan mengarahkan anak untuk berdoa sebelum makan setelah selesai berdoa anak-anak diarahkan untuk mencuci tangan terlebih dahulu kemudian anak makan bersama temannya. Setelah selesai makan anak merapikan tempat makannya dan kembali mencuci tangan dan membaca doa sesudah makan. Setelah selesai, guru melakukan tanya jawab tentang kegiatan yang telah dilakukan. Guru memberikan informasi tentang kegiatan yang akan dilakukan besok, guru mempersiapkan anak untuk pulang dan guru membimbing anak untuk mengucapkan doa keselamatan dan doa pulang sekolah dan di akhiri dengan ucapan salam.

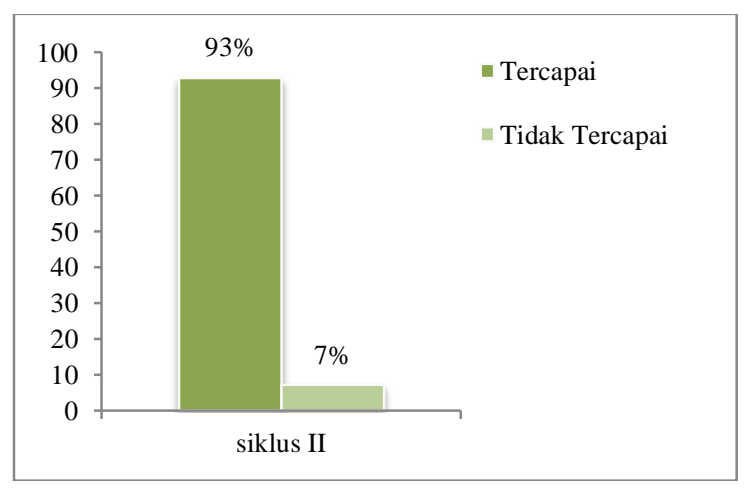

Gambar 3. Diagram Hasil Analisis Aktivitas Mengajar Guru Siklus II

Hasil observasi mengajar guru pada siklus II ini sesuai dengan pedoman lembar obsevasi sebanyak 14 aspek yang diamati. Pada siklus II skor yang dicapai oleh guru dari 14 aspek yaitu 13 aspek setara dengan 93\%, diantaranya yaitu: (1) guru mempersiapkan anak untuk belajar dan membuka pembelajaran dengan kegiatan imtaq, (2) guru menyiapkan alat dan bahan pembelajaran, (3) guru menyampaikan tujuan pembelajaran, (4) guru menjelaskan materi pembelajaran yang akan dilaksanakan, (5) guru memperlihatkan media-media yang akan digunakan dalam kegiatan kelas memasak, (6) guru meminta anak untuk memperhatikan dan menyebutkan gambar yang di tunjukkan, (7) guru memperlihatkan alat-alat yang digunakan dalam kegiatan kelas memasak, (8) guru memberikan 2 pertanyaan sederhana kepada anak tentang pembelajaran yang akan dilaksanakan, (9) guru meminta anak untuk menyebutkan apa saja alat-alat yang digunakan dalam kegiatan kelas memasak, (10) guru membimbing dan mengawasi anak dalam proses pembelajaran kegiatan memasak, (11) guru meminta anak mendemonstrasikan kegiatan kelas memasak sesuai yang telah dicontohkan guru, (12) guru melakukan proses recall atau mengingatkan kembali apa-apa yang telah dilakukan, (13) guru memberikan reward atau pujian kepada anak, (14) guru memberikan kesimpulan tentang pembelajaran yang telah dilakukan. Sedangkan aspek yang tidak tercapai sebanyak 1 aspek dengan persentase 7\% diantaranya yaitu: (1) guru menyampaikan tujuan pembelajaran.

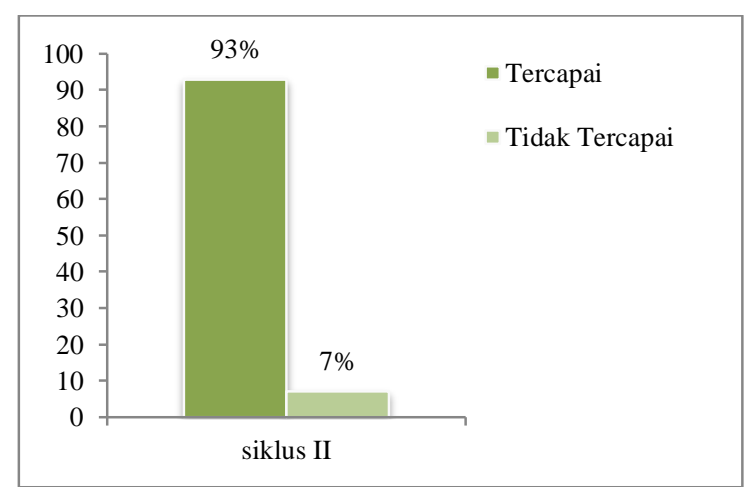

Gambar 4. Diagram Hasil Analisis Aktivitas Belajar Anak Didik Siklus II

Hasil analisis proses pembelajaran Siklus II aktivitas belajar anak yang diamati menggunakan lembar observasi aktivitas belajar anak terdiri atas 14 aspek. Analisis hasil aktivitas belajar anak pada siklus II yang dicapai anak adalah 13 aspek dari 14 aspek dengan persentase 93\% yang meliputi: (1) anak siap untuk belajar dan mengawali pembelajaran dengan kegiatan imtaq, (2) anak memperoleh alat dan bahan pembelajaran, (3) anak menyebutkan tujuan pembelajaran, (4) anak menyebutkan kembali materi pembelajaran yang akan dilaksanakan, (5) anak menyebutkan media-media yang akan digunakan dalam kegiatan kelas memasak, (6) anak memperhatikan dan menyebutkan gambar yang di tunjukkan, (7) anak memperlihatkan alat-alat yang akan digunakan dalam kegiatan kelas memasak, (8) anak menjawab 2 pertanyaan sederhana dari guru tentang pembelajaran yang dilaksanakan, (9) anak menyebutkan alat-alat yang digunakan dalam kegiatan kelas memasak, (10) anak memperoleh bimbingan dalam proses pembelajaran kegiatan memasak, (11) anak mendemonstrasikan kegiatan kelas memasak sesuai yang telah dicontohkan guru, (12) anak 
menyebutkan kembali apa-apa yang telah dilakukan, (13) anak memperoleh reward atau pujian dari guru, (14) anak menyebutkan kesimpulan tentang pembelajaran yang telah dilakukan. Sedangkan aspek yang tidak tercapai yaitu 1 aspek dengan persentase 7\% yaitu: (1) anak menyebutkan tujuan pembelajaran.

Tabel 3. Nilai Klasikal pada Siklus II

\begin{tabular}{lcc}
\hline \multicolumn{1}{c}{ Kategori } & Jumlah & $\mathbf{( \% )}$ \\
\hline $\begin{array}{l}\text { Berkembang Sangat } \\
\text { Baik }\end{array}$ & 11 & $74 \%$ \\
\hline $\begin{array}{l}\text { Berkembang Sesuai } \\
\text { Harapan }\end{array}$ & 2 & $13 \%$ \\
\hline Mulai Berkembang & 2 & $13 \%$ \\
\hline Belum Berkembang & 0 & 0 \\
\hline \multicolumn{1}{c}{ Jumlah } & 15 & $100 \%$ \\
\hline
\end{tabular}

Berdasarkan hasil yang diperoleh pada tabel 3, terlihat bahwa secara klasikal kegiatan meningkatkan kemampuan motorik halus anak melalui kegiatan kelas memasak sebagian besar anak sudah dapat melaksanakan kegiatan dengan baik yaitu $87 \%$. Anak yang memperoleh bintang (****) atau Berkembang Sangat Baik (BSB) yaitu 11 orang anak didik dengan persentase $74 \%$, nilai bintang (***) atau Berkembang Sesuai Harapan (BSH) yaitu sebanyak 2 orang anak dengan peresentase 13\%. Dan yang memperoleh nilai bintang (**) atau Mulai Berkembang (MB) yaitu sebanyak 2 orang anak didik dengan persentase $13 \%$. Walaupun masih terdapat anak didik yang memperoleh nilai bintang $(* *)$ atau Mulai Berkembang tetapi dapat dikatakan bahwa sebagian besar anak didik dipandang telah mampu menyelesaikan tugas-tugas yang telah ditetapkan sesuai indikator penilaian yaitu $85 \%$ dalam penelitian ini khususnya dalam pelaksanaan siklus II. Hal ini sejalan dengan (Wahyuni, Efastri, \& Fadillah, 2018) mengatakan bahwa kemampuan motorik halus anak meningkat disetiap siklus dengan kegiatan memasak. Sehingga secara umum dapat dikatakan bahwa program kegiatan atau rangkaian pelaksanaan pembelajaran dalam meningkatkan kemampuan motorik halus anak melalui kegiatan kelas memasak di Kelompok B1 RA Wildaanun Rabbaniyyun Kendari dipandang telah terselesaikan dan mencapai indikator kinerja yaitu $87 \%$. Penggunaan kegiatan memasak dalam upaya meningkatkan kemampuan motorik halus pada penelitian ini dapat dikatakan telah terlaksana dengan baik dan efektif dalam meningkatkan kemampuan motorik halus anak. Hal ini didukung oleh penelitian pengembangan yang dilakukan oleh
(Hasis, 2020) bahwa model permainan kelas memasak untuk meningkatkan motorik halus anak usia dini memenuhi aspek praktis sehingga layak untuk digunakan.

\section{KESIMPULAN DAN SARAN Kesimpulan}

Berdasarkan hasil observasi dan hasil penelitian aktivitas anak yang telah dilakukan, maka dapat ditarik kesimpulan sebagai berikut: Hasil observasi aktivitas mengajar guru pada siklus I dari 14 aspek yang diamati, namun hanya 11 aspek yang dicapai oleh guru dengan diperoleh nilai presentase $78 \%$. Dan hasil aktivitas belajar anak pada siklus I dari 14 aspek yang diamati, 11 aspek yang dapat dicapai oleh anak dengan perolehan presentase $78 \%$. Hasil belajar anak pada siklus I terdapat 7 orang anak yang mendapatkan nilai (****) atau Berkembang Sangat Baik (BSB) dan 4 orang anak yang mendapat nilai bintang $(* * *)$ atau Berkembang Sesuai Harapan (BSH) dengan presentase mencapai $74 \%$. Hasil observasi aktivitas mengajar guru pada siklis II dari 14 aspek yang diamati, 13 aspek yang tercapai dengan presentase 93\% dan hasil aktivitas belajar anak pada siklus II dari 14 aspek yang diamati, 13 aspek yang dicapai oleh anak dengan presentase 93\%. Hasil belajar anak pada siklus II terdapat 11 orang anak yang memperoleh nilai bintang $(* * * *)$ atau Berkembang Sangat Baik (BSB) 2 orang anak yang memperoleh nilai bintang $(* * *)$ atau Berkembang Sesuai Harpan dengan presentase ketuntasan klasikal 87\%. Dengan demikian dapat disimpulkan bahwa kemampuan motorik halus anak dapat ditingkatkan melalui kegiatan kelas memasak di kelompok B1 RA Woldaanun Rabbaniyyun Kendari.

\section{Saran}

Setelah melaksanakan tindakan penelitian maka peneliti menyarankan hal-hal diantaranya sebaiknya guru menggunakan pembelajaran yang menarik bagi anak dalam kegiatan kelas memasak sebagai salah satu cara untuk meningkatkan kemampuan motorik halus anak karena hasil penelitian bahwa melalui kegiatan kelas memasak dapat meningkatkan kemampuan motorik halus anak.

\section{DAFTAR PUSTAKA}

Angraeni, N., Arvyaty, \& Salim. (2018). Meningkatkan Kemampuan Anak Melalui Media Papan Flanel. Jurnal Riset Golden Age PAUD UHO 1(3), 190-194. 
http://dx.doi.org/10.36709/jrga.v1i3.910 5

Darwati., Wijayanti, A. \& Azizah, E. N. (2019). Peningkatan Kemampuan Motorik Anak Usia 3-4 Tahun melalui Kegiatan Fun Cooking. Jurnal Ilmiah Pendidikan Citra Bakti, 6(2), 156-166.

DOI: 10.5281/zenodo.3551669

Fardiah., Murwani, S. \& Dhieni, N. (2020). Meningkatkan Kemampuan Kognitif Anak Usia Dini Melalui Pembelajaran Sains. Jurnal Obsesi: Jurnal Pendidikan Anak Usia Dini, 4(1), 133-140. DOI: 10.31004/obsesi.v4i1.254

Hasis, P. K. (2020). Pengembangan Model Permainan Cooking Class untuk Meningkatkan Motorik Halus Anak Usia Dini di Taman Kanak-Kanak Yapi Jaya Makassar. Jurnal Tunas Cendekia, 3(2), 172-183.

Indraswari, L. (2012). Peningkatan Perkembangan Motorik Halus Anak Usia Dini Melalui Kegiatan Mozaik di Taman Kanak-Kanak Pembina Agam. Junal Imiah Pesona PAUD, 1(3), 1-13. https://doi.org/10.24036/1633

Laely, K. \& Subiyanto. (2020). Cooking Class Berbasis Kearifan Lokal Meningkatkan Motorik Halus Anak di Daerah Miskin. Jurnal Obsesi: Jurnal Pendidikan Anak Usia Dini, 4(2), 923-931. DOI: 10.31004/obsesi.v4i2.466

Nur, L., Hafina, A., \& Rusmana, N. (2020). Kemampuan Kognitif Anak Usia Dini dalam Pembelajaran Akuatik. Sholaria: Jurnal Pendidikan dan Kebudayaan, 10(1), 42-50.

Nurhapita, A., Enoh., \& Inten, D. N. (2019). Program Kegiatan Cooking Class untuk Anak Usia Dini di Kelas Koki Cilik Jakarta. Prosiding Pendidikan Guru PAUD, 51-86. http://dx.doi.org/10.29313/.v0i0.18896

Pitaloka, V., Ineu, N. \& Umar. (2015). Pengembangan Kemampuan Motorik Halus pada Anak Usia Dini Melaui Balls Melody. Cakrawala: Jurnal Pendidikan Anak Usia Dini, 6(2), 81-88. https://doi.org/10.17509/cd.v6i2.10523
Pura, D. N. \& Asnawati. (2019). Perkembangan Motorik Halus Anak Usia Dini Melalui Kolase Media Serutan Pensil. Jurnal Ilmiah Potensia, 4(2), 131-140. https://doi.org/10.33369/jip.4.2.131-140

Rasid, J., Wondal, R. \& Samad, R. (2020). Kajian Tentang Kegiatan Cooking Class dalam Meningkatkan Keterampilan Motorik Halus Anak Usia 5-6 Tahun. Jurnal Ilmiah Cahaya PAUD, 2(1), 8291. http://dx.doi.org/10.33387/cp.v2i1.2041

Wahyuni, S., Efastri, S. M. \& Fadillah, S. (2018). Meningkatkan Kemampuan Motorik Halus melalui Kegiatan Cooking Class Anak Usia 5-6 Tahun di TK Melati Pekan Baru. PAUD Lectura: Jurnal Pendidikan Anak Usia Dini, 2(1), 61-72.

https://doi.org/10.31849/paudlectura.v2i 01.2005 